\title{
Natural occurrence of hexavalent chromium in a sedimentary aquifer in Urânia, State of São Paulo, Brazil
}

\author{
CHRISTINE BOUROTTE ${ }^{1}$, REGINALDO BERTOLO $^{2}$, MARTA ALMODOVAR ${ }^{3}$ and RICARDO HIRATA ${ }^{4}$ \\ ${ }^{1}$ Instituto de Geociências, Universidade de São Paulo \\ ${ }^{2}$ Instituto de Geociências, Universidade de São Paulo \\ Rua do Lago, 562, Cidade Universitária, 05508-080 São Paulo, SP, Brasil \\ ${ }^{3}$ CETESB, Companhia de Tecnologia de Saneamento Ambiental do Estado de São Paulo \\ Av. Professor Frederico Hermann Jr., 345, Alto de Pinheiro, 05459-900 São Paulo, SP, Brasil \\ ${ }^{4}$ Instituto de Geociências, Universidade de São Paulo \\ Rua do Lago, 562, Cidade Universitária, 05508-080 São Paulo, SP, Brasil \\ Manuscript received on August 6, 2008; accepted for publication on December 19, 2008; \\ presented by ALCIDES N. SIAL
}

\begin{abstract}
Anomalous concentrations of hexavalent chromium have been detected in groundwater of the Adamantina Aquifer in at least 54 municipalities located in the northwestern region of the State of São Paulo, southeast Brazil, occasionally exceeding the permitted limit for human consumption $\left(0.05 \mathrm{mg} \cdot \mathrm{L}^{-1}\right)$. An investigation was conducted in the municipality of Urânia, where the highest concentrations of chromium were detected regionally. It was defined that the origin of this contamination is natural, since high concentrations of chromium were detected in aquifer sandstones (average of $221 \mathrm{ppm})$ and also in pyroxenes $(6000 \mathrm{ppm})$, one of the main heavy minerals found in the sediments. Besides, no other possible diffuse or point sources of contamination were observed in the study area. Stratification of groundwater quality was observed and the highest concentrations of $\mathrm{Cr}^{6+}$ were detected the base of the aquifer $\left(0.12 \mathrm{mg} . \mathrm{L}^{-1}\right)$, where groundwater shows elevated values for redox potential $(472.5 \mathrm{mV})$ and $\mathrm{pH}(8.61)$. The origin of $\mathrm{Cr}^{6+}$ in water may be associated with the weathering of pyroxene (augite), followed by the oxidation of $\mathrm{Cr}^{3+}$ by manganese oxides. The highest concentrations of $\mathrm{Cr}^{6+}$ are probably related to desorption reactions, due to the anomalous alkaline $\mathrm{pH}$ found in groundwater at the base of the aquifer.
\end{abstract}

Key words: chromium, groundwater, aquifer, natural contamination.

\section{INTRODUCTION}

Chromium has been identified as a public health problem due to its toxic effects even at low exposure levels (ATSDR 2000). In the environment, chromium exists in two main oxidation states, $\mathrm{Cr}^{3+}$ and $\mathrm{Cr}^{6+}$, which develop different geochemical and biological activities, since $\mathrm{Cr}^{3+}$ is an essential metal nutrient and $\mathrm{Cr}^{6+}$ is carcinogenic. $\mathrm{Cr}^{6+}$ is more mobile, labile and toxic than $\mathrm{Cr}^{3+}$ and their distribution is regulated by redox reac-

Correspondence to: Reginaldo Bertolo

E-mail: bertolo@igc.usp.br tions in natural waters. Under acidic and reducing conditions, $\mathrm{Cr}^{3+}$ species will predominate in water, while $\mathrm{Cr}^{6+}$ species will prevail under alkaline and mildly oxidizing conditions.

Groundwater contamination by chromium is generally associated with such anthropic activities as steelworks, electroplating, leather tanning and chemical manufacturing. High levels of chromium associated with natural sources are not common. Nevertheless, mafic and ultramafic rocks generally show higher concentrations of chromium than other rock types. Con- 
centrations of naturally occurring hexavalent chromium have been reported in groundwater in the Aroma Red Sands Aquifer, California (Gonzalez et al. 2005), at Léon Valley, Mexico (Robles-Camacho and Armienta 2000), in the western Mojave Desert, California (Ball and Izbicki 2004) and Arizona (Robertson 1995).

Although the natural presence of chromium in aquifers is scarce and little studied, concentrations of chromium higher than the recommended value for drinking water $\left(0.05 \mathrm{mg} . \mathrm{L}^{-1}\right)$ have been known since 1977 in the Adamantina Aquifer (Almodovar and Pacheco 1995), located in the northwestern portion of the State of São Paulo. Water supplies in this region are primarily obtained via deep groundwater wells, most of which are managed by public water supply companies.

The main objective of this paper is that of characterizing the distribution of chromium species in groundwater of the Adamantina Aquifer and present the results of an investigation performed in the municipality of Urânia (Fig. 1), where the highest concentrations were detected. The concentration of major ions and water quality parameters were also measured and their relationship with chromium occurrence was considered, as well as the relationship between chemical species and well depth. The results shown in this paper are part of a wider study and some interpretations of the occurrence and distribution of chromium are also discussed.

\section{STUDY AREA}

\section{Geological Setting}

The study area is located in the Paraná Basin, which is a volcanic-sedimentary basin that covers virtually 1 million $\mathrm{km}^{2}$ in Brazil. More specifically, the study site is located in the western part of the Paulista Plateau, which covers $50 \%$ of the State of São Paulo. The parent rock consists of sedimentary rocks of the Bauru Basin (Upper Cretaceous age) and overlays basalts of the Serra Geral Formation (Jurassic-Cretaceous age).

The Bauru Basin covers an area of 104,000 km² and $42 \%$ of the area of the State of São Paulo. Based on the conception of Fernandes and Coimbra (2000), the Bauru Basin has two chronocorrelated geological units, namely: the Caiuá and Bauru Groups. These two depositional systems have been formed under semi-arid to desertic climate conditions, from the border to interior portions of the basin. The Caiuá Group is subdivided into the Rio Paraná, Goio-Erê and Santo Anastácio Formations, which are present in the western portion of the State of São Paulo. The Bauru Group, which is predominant in the State of São Paulo, outcrops in oriental domains of the Basin and is subdivided into the Vale do Rio do Peixe, Araçatuba, São José do Rio Preto, Presidente Prudente and Marília Formations (Fig. 1).

In this context, sedimentary rocks of the Vale do Rio do Peixe Formation or, in other words, the Adamantina Formation conceived by Soares et al. (1980), outcrop in the municipality of Urânia. This stratigraphic unit is constituted of well-sorted fine to very fine sandstones, interbedded with siltstones. Carbonate cementation is found locally. The sandstones are disposed in submetric tabular layers of massive aspect, presenting zones of coarse tabular bedding and zones with tabular and through cross-bedding.

Fernandes and Coimbra (2000) suggest that deposition of the Vale do Rio do Peixe Formation occurred primarily by eolic action in extensive plain-like areas and, secondarily, by occasional torrents, forming wadis deposits. Finally, the authors suggest that the lower contact of the Vale do Rio do Peixe Formation is gradual with the Santo Anastácio Formation or, as occurs in the study area, discordant and directly on the basalts of the Serra Geral Formation.

Brandt Neto et al. (1985) indicate that the mineralogy of the sediments is mainly composed of quartz and, secondarily, feldspars, kaolinite, montmorillonite, opaque minerals and carbonates as cement. The origin of the sedimentary rocks is related to the deposition of sediments caused by the erosion and transport of other phanerozoic sediments, metamorphic rocks of the Araxá and Canastra Groups, basalts of the underlying Serra Geral Formation and alkaline rocks of the Triângulo Mineiro (A.M. Coimbra, unpublished data).

The average thickness of the Bauru Group is around $100 \mathrm{~m}$. Greater thickness generally occurs on the crests of hills between the main rivers of the western portion of the State of São Paulo. In the Urânia region, the sedimentary rocks were found to have a thickness of up to $160 \mathrm{~m}$ (Almodovar 2000).

The Serra Geral Formation is formed by basaltic rocks and underlies the Bauru Basin. Within the re- 


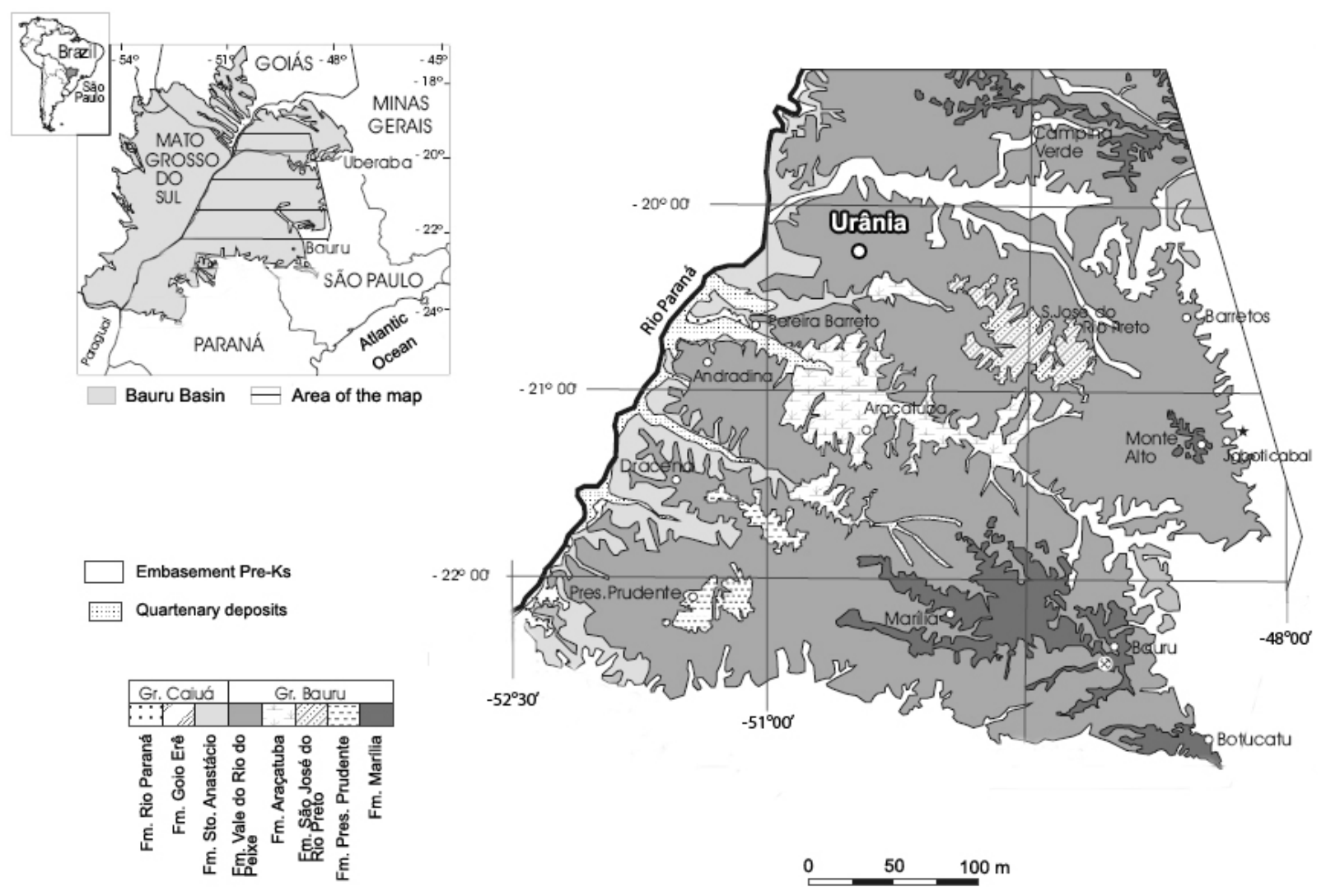

Fig. 1 - Location of the study area and stratigraphy of Bauru Basin (modified from Fernandes and Coimbra 2000).

gion, the Serra Geral Formation has a thickness of between 500 and $1500 \mathrm{~m}$. In the Urânia region, deep supply wells exploiting groundwater from the underlying Guarani Aquifer show basaltic rocks with a thickness of around $900 \mathrm{~m}$.

\section{Hydrogeological Setting}

There are two main hydro-stratigraphic units in this region, namely: the Bauru Aquifer System, which constitutes the main source of water supply, and the Serra Geral Aquifer, represented by basalts of the underlying Serra Geral Formation. The municipality of Urânia is located in the context of the traditionally named Adamantina Aquifer, in concordance with designation of the Adamantina Formation by Soares et al. (1980).

The Adamantina Aquifer can be characterized as a granular and continuous unit, and shows an unconfined to semi-confined behavior. Its potentiometric surfaces are strongly influenced by the geomorphology of the area, where groundwater divides coincide with the drainage basins and the local effluent rivers correspond to the discharge areas of the aquifer (Hirata et al. 1997). This aquifer is a moderately permeable formation, with average values of hydraulic conductivity and transmissivity close to $1.0 \mathrm{E}-5 \mathrm{~m} / \mathrm{sec}$ and $40 \mathrm{~m}^{2} /$ day, respectively (DAEE 1976).

The Serra Geral Aquifer system is constituted by flood basalts and associated intrusive rocks. It is characterized as a fractured, unconfined to semi-confined, discontinued, anisotropic and heterogeneous aquifer.

The northwestern region of the State of São Paulo shows an average temperature of $20^{\circ} \mathrm{C}$ and average precipitation of $1271 \mathrm{~mm}$ per year, which is distributed in an uneven form, with most precipitation occurring in the rainy period from December to March, when recharge of the aquifers takes place. The dry season is from April to November, when potential evapotranspiration is much higher than precipitation (DAEE 1976). 


\section{SAMPling AND ANALYTICAL Methods}

Table I presents a summary of the groundwater sampling events from 1977 to 1999. Data from 144 deep supply wells located in 54 cities of the study area were initially obtained at a public water supply company. These data include in-situ and laboratory parameters obtained between 1977 and 1993. Fieldwork activities were then conducted in 12 localities in the region during December 1994, in order to complement the geographical investigation of chromium distribution (Almodovar and Pacheco 1995).

From June 1998 to June 1999, groundwater samples from 31 wells located in the municipality of Urânia were analyzed in order to assess variation of chromium concentrations with depth and pumping time. During sampling activities, water from public and private supply wells was collected, together with water from handdug shallow supply wells. In order to evaluate variation of chromium concentrations over a pumping period of 24 hours, a sampling program was performed during several pumping intervals at two deep supply wells (PP02 and PP04).

Samples collected between 1977 and 1993 were obtained and analyzed by a public water supply company. Little information is available regarding sampling techniques, sample preservation and analytical methods.

Samples collected between 1994 and 1999 were obtained at the nearest tap, located prior to the water tank. All wells were equipped with electric pumps. These samples were split and an aliquot for determination of cations and metals was filtered through a $0.45 \mu \mathrm{m}$-pore filter and acidified with ultrapure $\mathrm{HNO}_{3}$ to $\mathrm{pH}<2.0$. The aliquot for anion determination was just stored at a temperature of $4^{\circ} \mathrm{C}$ until analysis.

Measurements of $\mathrm{pH}, \mathrm{Eh}, \mathrm{EC}, \mathrm{Cr}^{6+}$ and alkalinity of water samples were performed in the field. Alkalinity analysis was performed by titration with $\mathrm{H}_{2} \mathrm{SO}_{4}$ using an end-point based on the Gran plot (Appelo and Postma 1993). Analytical methods for chemical species quantified in the sampled groundwater are summarized in Table II.

In performing chemical analyses, QA/QC procedures included the analysis of blanks, spikes and duplicate samples, which indicated favorable results, and by checking ion balances, which showed errors for the analyses generally within $\pm 10 \%$. Saturation indexes of calcite and dolomite were calculated using PhreeqC (Parkhurst and Appelo 1999).

\section{RESULTS AND DISCUSSION}

REgional Distribution OF TOTAL CHROMIUM AND CR ${ }^{6+}$

A general assessment of total and hexavalent chromium concentrations in groundwater was conducted in the Northwestern region of the State of São Paulo based on existing data gathered between 1977 and 1993 (Almodovar and Pacheco 1995). Total chromium is distributed in various municipalities and districts of the region. In some localities, concentrations are lower than or equal to the potability limit $\left(0.05 \mathrm{mg} . \mathrm{L}^{-1}\right)$, whereas in many others concentrations vary from this limit up to $0.155 \mathrm{mg} . \mathrm{L}^{-1}$.

Table III shows a summary of basic statistics regarding chromium concentrations detected in groundwater at various localities during this period. Figure 2 shows a regional map with indication of the concentrations of total and hexavalent chromium obtained in groundwater in the study region.

Around 39\% of all available analyses showed concentrations of chromium higher than (or equal to) the potability limit. The values showed a great degree of variation between different localities in the region and a clear distribution pattern could not be obtained. However, comparing the concentrations found in wells installed in the Adamantina and Serra Geral aquifers, it was observed that the highest concentrations of total chromium occurred in groundwater from the Adamantina Aquifer. Concentrations varied between 0.005 and $0.155 \mathrm{mg} . \mathrm{L}^{-1}$, with the highest concentrations in the municipality of Urânia, whereas concentrations varied from 0.006 to $0.018 \mathrm{mg} . \mathrm{L}^{-1}$ in basalts of the Serra Geral Aquifer.

\section{NATURAL VERSUS ANThropic SOURCES}

Anthropic processes and natural sources can be considered as possibilities for assessing the origin of chromium concentrations in groundwater. The Urânia region, a small town of approximately 10,000 inhabitants, was chosen for a detailed assessment of these possibilities.

Land use characteristics of the area were checked and most of the sampling sites were located in resid- 
TABLE I

Characteristics of groundwater sampling events from 1977 to 1999.

\begin{tabular}{|c|c|c|c|c|}
\hline $\begin{array}{l}\text { Sampling date/ } \\
\text { Source }\end{array}$ & Locality & Type/Number & Parameters for in situ analysis & Parameters for laboratory analysis \\
\hline $\begin{array}{l}1977-1993 \\
\text { (public water } \\
\text { supply company) }\end{array}$ & $\begin{array}{l}\text { Data from } \\
144 \text { wells in } \\
54 \text { cities }\end{array}$ & $\begin{array}{l}2 \text { shallow wells } \\
121 \text { deep wells }\end{array}$ & Electrical Conductivity (EC) & $\mathrm{Cr}_{\text {tot }}, \mathrm{Cr}^{6+}, \mathrm{NO}_{3}^{-}$ \\
\hline $\begin{array}{l}\text { December } 1994 \\
\text { (Almodovar and } \\
\text { Pacheco 1995) }\end{array}$ & 12 localities & $\begin{array}{l}1 \text { shallow well } \\
24 \text { deep wells }\end{array}$ & $\begin{array}{l}\text { Air and watPb } \mathrm{Pb}^{2+}, \text { er temperatures, } \\
\mathrm{pH}, \mathrm{EC}, \text { total dissolved solids }\end{array}$ & $\mathrm{Cr}^{6+}$ \\
\hline $\begin{array}{l}\text { March } 1995 \\
\text { (Almodovar and } \\
\text { Pacheco 1995) }\end{array}$ & $\begin{array}{l}\text { Urânia } \\
\text { Santa Salete }\end{array}$ & $\begin{array}{l}\text { P2, P4 and P5 wells } \\
\text { P1 well }\end{array}$ & $\begin{array}{l}\text { Air and water temperatures, } \mathrm{pH} \text {, } \\
\text { EC, Eh, total dissolved solids }\end{array}$ & $\begin{array}{l}\mathrm{Na}^{+}, \mathrm{K}^{+}, \mathrm{SiO}_{2}, \mathrm{Cr}_{\text {tot }}, \mathrm{Cr}^{6+} \\
\mathrm{SO}_{4}^{2-}, \mathrm{F}^{-}, \mathrm{Fe}_{\text {tot }}, \mathrm{Mn}^{2+}, \mathrm{Al}^{3+} \\
\mathrm{NO}_{3}^{-}, \mathrm{HCO}_{3}^{-}\end{array}$ \\
\hline $\begin{array}{l}\text { January } 1995 \\
\text { (Almodovar and } \\
\text { Pacheco 1995) }\end{array}$ & Urânia & P9 well & $\begin{array}{l}\text { Air and water temperatures, } \mathrm{pH}, \\
\mathrm{EC}, \mathrm{Eh} \text {, total dissolved solids }\end{array}$ & $\begin{array}{l}\mathrm{Cl}^{-}, \mathrm{SO}_{4}^{2-}, \mathrm{Ca}^{2+}, \mathrm{Mg}^{2+}, \mathrm{Fe}_{\text {tot }} \\
\mathrm{Al}^{3+}, \mathrm{Cr}_{\text {tot }}\end{array}$ \\
\hline $\begin{array}{l}\text { Four rounds of } \\
\text { sampling (one in } \\
\text { each season) from } \\
\text { June } 1998 \text { to } \\
\text { June } 1999\end{array}$ & Urânia & $\begin{array}{l}14 \text { shallow hand-dug } \\
\text { wells and } 17 \text { deep } \\
\text { supply wells } \\
\text { PP02 and PP04 for } \\
\text { study of chromium } \\
\text { concentrations with } \\
\text { pumping time }\end{array}$ & $\begin{array}{l}\text { Air and water temperatures, } \mathrm{pH}, \\
\mathrm{EC}, \mathrm{Eh}, \mathrm{O}_{2}, \mathrm{Cr}^{6+} \text {, Alkalinity }\end{array}$ & $\begin{array}{l}\mathrm{Ag}^{+}, \mathrm{Al}^{3+}, \mathrm{Ba}^{2+}, \mathrm{Br}^{-}, \mathrm{Ca}^{2+}, \\
\mathrm{Cd}^{2+}, \mathrm{Cl}^{-}, \mathrm{Cr}_{\text {tot }}, \mathrm{Cu}^{2+}, \mathrm{Fe}_{\text {tot }}, \\
\mathrm{F}^{-}, \mathrm{K}^{+}, \mathrm{Mg}^{2+}, \mathrm{Mn}^{2+}, \mathrm{Na}^{+}, \\
\mathrm{Ni}^{2+}, \mathrm{NO}_{2}^{-}, \mathrm{NO}_{3}^{-}, \mathrm{Pb}^{2+}, \mathrm{PO}_{4}^{3-}, \\
\mathrm{SO}_{4}^{2-}, \mathrm{Sr}^{2+}, \mathrm{Zn}^{2+}\end{array}$ \\
\hline
\end{tabular}

TABLE II

Analytical methods used during sampling events from 1994 to 1999.

\begin{tabular}{l|l}
\hline Chemical species & Analytical method \\
\hline $\mathrm{Cr}^{6+}$ & $\begin{array}{l}\text { Colorimetry }- \text { Aquaquant } \\
1.14402 \text { MERCK }\end{array}$ \\
\hline $\mathrm{Al}^{3+}, \mathrm{Ag}^{+}, \mathrm{Ba}^{2+}, \mathrm{Ca}^{2+}$, & Atomic Absorption \\
$\mathrm{Cd}^{2+}, \mathrm{Cr}_{\text {tot }}, \mathrm{Cu}^{2+}, \mathrm{Fe}_{\text {tot }}$, & Spectrophotometry \\
$\mathrm{Mg}^{2+}, \mathrm{Mn}^{2+}, \mathrm{Ni}^{2+}$, & \\
$\mathrm{Pb}^{2+}, \mathrm{Sr}^{2+}, \mathrm{Zn}^{2+}$ & \\
\hline $\mathrm{K}^{+}, \mathrm{Na}^{+}$ & Flame photometry \\
\hline $\mathrm{Cl}^{-}, \mathrm{Br}^{-}, \mathrm{F}^{-}, \mathrm{SO}_{4}^{2-}$, & Ion Chromatography \\
$\mathrm{NO}_{3}^{-}, \mathrm{NO}_{2}^{-}, \mathrm{PO}_{4}^{3-}$ & (DIONEX 2010i) \\
\hline
\end{tabular}

TABLE III

Concentrations of chromium detected in 144 wells from 1977 to 1993

(Almodovar and Pacheco 1995).

\begin{tabular}{c|c|c|c|c|c}
\hline & N Samples & Mean & Standard Error & Minimum & Maximum \\
\cline { 2 - 6 } & & \multicolumn{4}{|c}{ mg.L. } \\
\hline Cr total & 266 & 0.048 & 0.07 & 0.005 & 0.9 \\
\hline $\mathrm{Cr}^{6+}$ & 108 & 0.045 & 0.03 & 0.0025 & 0.11 \\
\hline
\end{tabular}




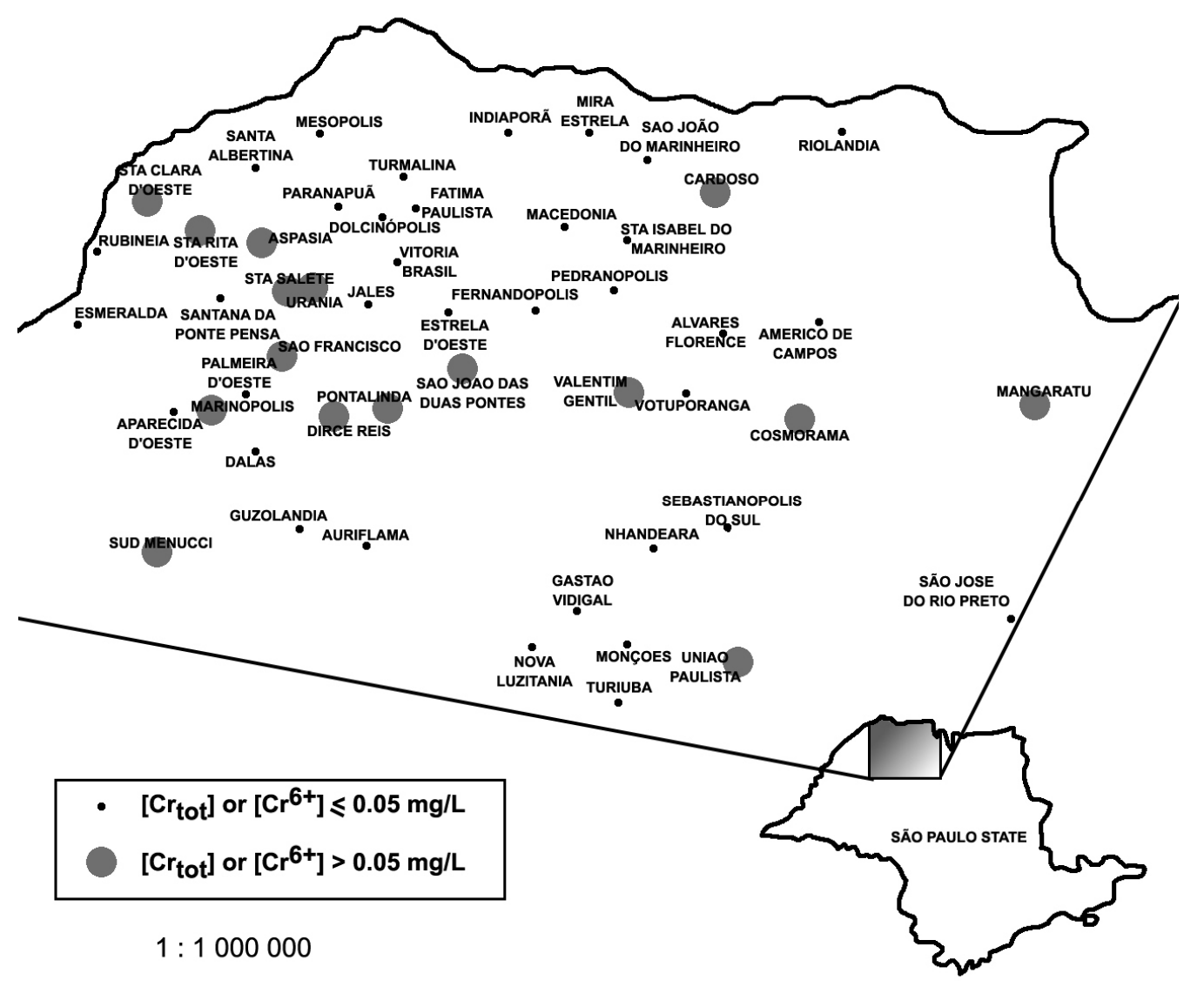

Fig. 2 - Distribution of chromium concentrations in space (modified from Almodovar and Pacheco 1995).

ential or agricultural areas. Agriculture is the main economic activity in the area, primarily fruit cultivation (grape and pineapple) and small-scale cattle farming. Thus, the application of fertilizers and pesticides could possibly be a significant diffuse source of the chromium found in the aquifer. The chemical composition of fertilizers and pesticides commonly used in the Urânia area was then checked and no significant concentration of chromium was present.

Point sources of contamination, like steelworks, electroplating, leather tanning and chemical manufacturing, were not found to be present in the study area. Only small industries are present, such as rice processing and furniture manufacturing, which do not show an associated contaminant load of chromium. Besides this, these types of point sources of contamination would generate contamination plumes with limited and defined geometry, which is not the widespread pattern of chromium contamination that has been observed.

Thus, there was no evidence of an anthropic source of chromium contamination in the study area, which reinforced the hypothesis of natural origin in the case of this contamination. This hypothesis was confirmed by Marcolan and Bertolo (2007), through chemical and mineralogical analysis using X-ray fluorescence, $\mathrm{X}$-ray diffraction and scanning electron microscopy (SEM-EDS) on borehole samples collected from the top to the base of the aquifer in Urânia. The results of this investigation indicated that:

(i) the concentration of chromium in sandstones is anomalous, with average and maximum values of 221 and 336 ppm, respectively, which are significantly higher than the reported average concentration in a generic sandstone $(35 \mathrm{mg} / \mathrm{kg})$ and soils from another regions in the State of São Paulo (26.3 mg/kg);

(ii) chromium concentrations attained values of 6000 ppm in pyroxene crystals (augite), which is one of the main heavy minerals found in the sandstones; 
(iii) chromium concentrations in clay minerals and iron hydroxides are also relatively high (up to $650 \mathrm{ppm}$ ).

\section{HydrogeochemicAl STUdy IN TOWN OF URÂNIA}

\section{Conceptual model}

The geological and hydrogeological features of the Adamantina Aquifer in Urânia are quite similar to those described for the aquifer regionally. The aquifer is unconfined to semi-confined, constituted of well-sorted fine to very fine sandstones with carbonate cementation, relatively homogeneous and isotropic in the scale of study, and with a thickness varying from 66 to $165 \mathrm{~m}$. The urban area of Urânia is located on the crest of a smooth hill, which corresponds to the local aquifer groundwater divide.

Groundwater flow lines that originate in this area converge to the Comprido Creek, which is considered as the main discharge area of the aquifer locally (Figure 3). The hydraulic gradient varies from 0.011 to 0.025 and the advective flow velocity of groundwater ranges from 20 to $400 \mathrm{~m} /$ year. Pumping tests showed a hydraulic conductivity value of $8.54 \mathrm{E}-6 \mathrm{~m} / \mathrm{sec}$ (F.A. Cagnon, unpublished data).

Three classes of supply wells were registered in Urânia, each representing conditions at a specific depth in the aquifer: private hand-dug wells (14), private 4" wells (10) and public 6" wells (7). In general, the private hand-dug wells (shallow wells) have a diameter of $1.2 \mathrm{~m}$ and reach an average depth of $11 \mathrm{~m}$, being characteristic of the shallow part of the aquifer, where a local groundwater flow system with a shorter transit time predominates. The private 4 " wells (intermediate wells) pump groundwater from intermediate depths in the aquifer, show an average depth of $57 \mathrm{~m}$ and are commonly cased with 4 " tubes to a depth of $20 \mathrm{~m}$. The public 6" wells (deep wells) extend to depths varying from 75 to $160 \mathrm{~m}$ and usually reach the top of basalts that comprise the Serra Geral Formation. These wells are continuously cased with 6 " tubes and filters that are installed from the intermediate to deep intervals of the aquifer. This situation might result in mixture of water from these layers. A regional system of groundwater flow predominates in the deep parts of the aquifer, with a longer transit time.

Potentiometric levels obtained from the set of wells indicate the occurrence of downward flow potential in the urban area and upward flow potential in the area of the Comprido Creek, which is confirmed by nearby well PP05, where results showed conditions of artesianism controlled by topography.

Three hydrochemical zones were identified in the Adamantina Aquifer in Urânia that are in accordance with the depths of the studied wells. The first hydrochemical zone is the Shallow Zone (up to $30 \mathrm{~m}$ ), associated with the private hand-dug wells (shallow wells) and exhibiting $\mathrm{Na}-\mathrm{Ca}-\mathrm{Cl}-\mathrm{NO}_{3}$ facies (Figure 3). The Intermediate Zone $(30-70 \mathrm{~m})$ is associated with the private $4 "$ wells (intermediate wells) and shows $\mathrm{Ca}-\mathrm{HCO}_{3}$ facies. The Deep Zone $(>70 \mathrm{~m}$ ) is associated with the public $6 "$ wells (deep wells) and shows $\mathrm{Na}-\mathrm{Ca}-\mathrm{HCO}_{3}$ facies.

Table IV shows the results of a statistical evaluation performed on the analytical results of water samples collected from shallow, intermediate and deep wells during four rounds of monitoring activities performed between June 1998 and June 1999. Elevated values of standard deviation were advective obtained for $\mathrm{Cr}_{\text {total }}$, $\mathrm{Cr}^{6+}, \mathrm{Fe}_{\text {total }}, \mathrm{Mn}^{2+}$ and $\mathrm{SO}_{4}^{2-}$, indicating that the calculated mean value is not representative for the aquifer. In general, an anomalous high concentration of these parameters detected in a sample resulted in a tendency for elevation of the mean value.

Table IV also shows the average chemical composition of water from well PP04, which may better represent hydrochemical conditions existing in the deep aquifer, below intermediate depths, as it is solely screened at the base of the aquifer. As mentioned previously, the public 6" wells are frequently screened from intermediate depths to the base of the aquifer. As a result, the concentrations shown for water from these wells may in fact be considered as representative of a mixture of water from these depths.

From shallow to deep groundwater zones, the results showed an increase in $\mathrm{pH}$ and $\mathrm{HCO}_{3^{-}}$concentrations and a decrease in electrical conductivity (EC), indicating a drop in salinity. Eh also decreased, but values indicate oxidizing conditions for the aquifer. Comparing the three groundwater categories, concentrations of $\mathrm{Na}^{+}, \mathrm{K}^{+}, \mathrm{Ba}^{2+}, \mathrm{Cl}^{-}$, and $\mathrm{NO}_{3^{-}}$are higher in the shallow zone. Water samples from the intermediate zone showed higher concentrations of $\mathrm{Ca}^{2+}$ and $\mathrm{Mg}^{2+}$, whereas con- 


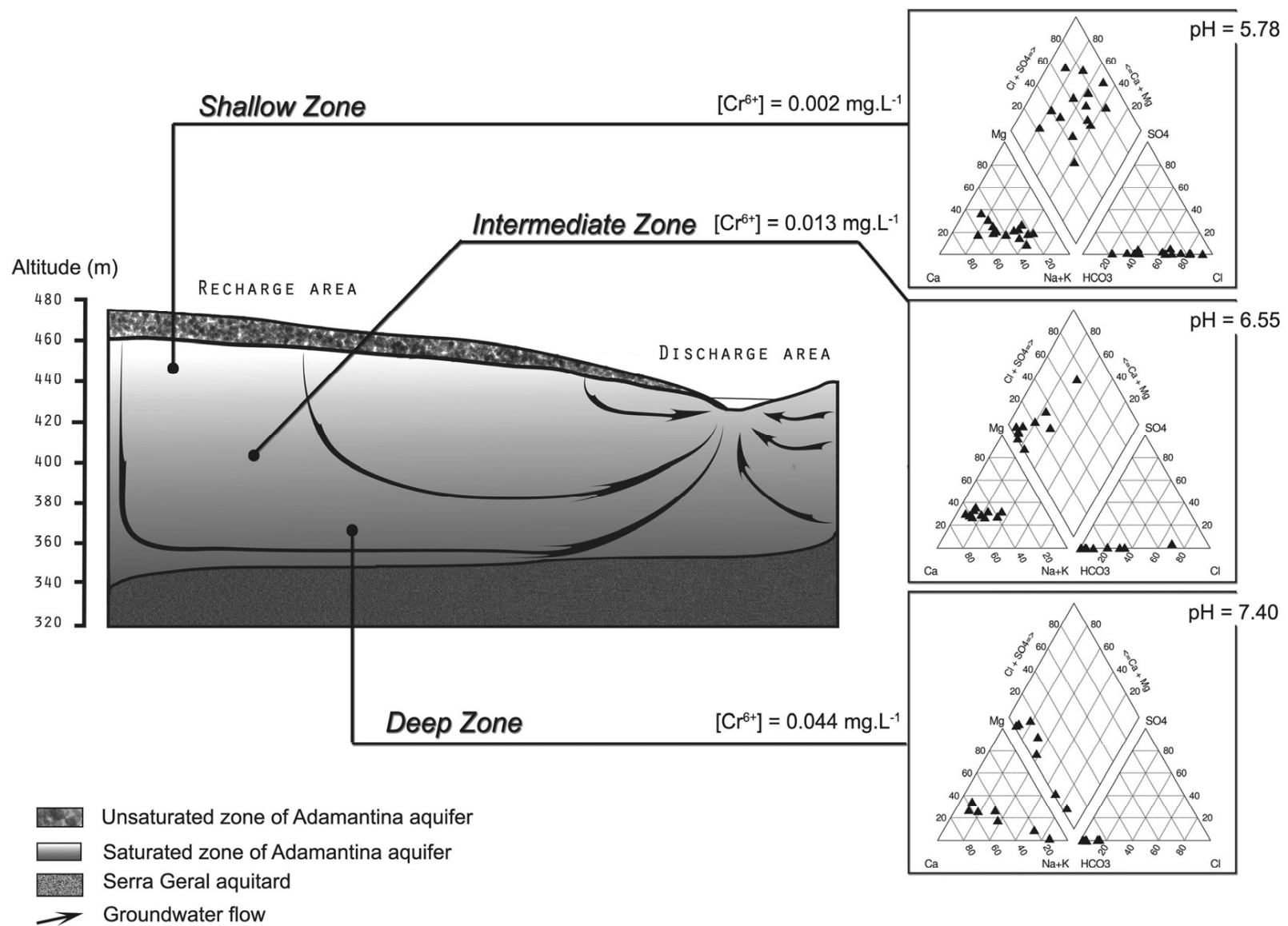

Fig. 3 - Conceptual hydrogeological and hydrogeochemical model of the Adamantina Aquifer in Urânia.

centrations of $\mathrm{HCO}_{3^{-}}, \mathrm{Na}^{+}, \mathrm{F}^{-}$, and $\mathrm{Cr}^{6+}$ are higher in the deep aquifer.

Comparing the mean values obtained for water samples collected in the different aquifer zones, $\mathrm{NO}_{3^{-}}$ and $\mathrm{Cl}^{-}$concentrations in shallow groundwater are 5 and 8 times higher than in deep groundwater, respectively. At shallow depths, nitrate concentrations exceed the drinking-water potability value of $45 \mathrm{mg} . \mathrm{L}^{-1}$ and gradually decrease with depth. The occurrence of nitrate in the proximity of the surface can be attributed to the organic charge of septic systems and/or fertilizer use. Its decrease, together with the decrease of EC (salinity), $\mathrm{Cl}^{-}$and $\mathrm{Na}^{+}$, can be attributed to contaminant dispersion and dilution processes. The sample collected from well PP04, which better represents hydrochemical conditions in the deep and unpolluted aquifer, shows very low nitrate content.

Water-rock interaction is better observed through such parameters as $\mathrm{pH}, \mathrm{HCO}_{3^{-}}, \mathrm{Na}^{+}, \mathrm{Ca}^{2+}$ and $\mathrm{Mg}^{2+}$. Increase in $\mathrm{pH}$ and $\mathrm{HCO}_{3^{-}}$concentrations from the top to the base of the aquifer controls the solubility of calcite and dolomite minerals (reaction 1), which exhibit increasing saturation values, until their saturation at the base of the aquifer (Table IV).

$$
\mathrm{CaCO}_{3}+\mathrm{H}^{+}=\mathrm{Ca}^{2+}+\mathrm{HCO}_{3^{-}}
$$

In addition, there is substantial enrichment of $\mathrm{Na}^{+}$in the aquifer relative to $\mathrm{Cl}^{-}$. The shallow and intermediate depths of the aquifer show a $\mathrm{Na} / \mathrm{Cl}$ molar ratio of 1.2 , which increases to 46.3 in the deep aquifer, thus indicating that the rock is providing the water with $\mathrm{Na}^{+}$. The increase in $\mathrm{Na}^{+}$, followed by a decrease in $\mathrm{Ca}^{2+}$ and $\mathrm{Mg}^{2+}$ concentrations and $\mathrm{Ca}^{2+} / \mathrm{HCO}_{3}-$ molar ratios, suggests the occurrence of a cation exchange reaction in the deeper parts of the aquifer (reaction 2).

$$
0.5 \mathrm{Ca}^{2+}+\mathrm{Na}-\mathrm{X}=0.5 \mathrm{Ca}-\mathrm{X}_{2}+\mathrm{Na}^{+}
$$


TABLE IV

Summary of analytical data of groundwater in shallow, intermediate and deep wells studied in the municipality of Urânia (four rounds of sampling from June 1998 to June 1999).

\begin{tabular}{|c|c|c|c|c|c|c|c|c|c|c|c|c|c|c|}
\hline & & \multirow{2}{*}{\multicolumn{4}{|c|}{$\begin{array}{c}\text { Shallow wells } \\
14\end{array}$}} & \multirow{2}{*}{\multicolumn{4}{|c|}{$\begin{array}{c}\text { Intermediate wells } \\
10\end{array}$}} & \multicolumn{5}{|c|}{ Deep wells } \\
\hline \multicolumn{2}{|c|}{$\mathrm{N}$ wells } & & & & & & & & & & & & & PP04 \\
\hline Parameter & Unit & Mean & Std. & Min. & Max. & Mean & Std. & Min. & Max. & Mean & Std. & Min. & Max. & \\
\hline Depth & $\mathrm{m}$ & 11.4 & 4.5 & 5.2 & 18.0 & 57.1 & 17.5 & 40.0 & 100.0 & 130.6 & 30.8 & 75.0 & 160.0 & 109.2 \\
\hline Temperature & ${ }^{\circ} \mathrm{C}$ & 25.5 & 3.0 & 19.9 & 30.5 & 26.3 & 1.9 & 22.9 & 30.1 & 25.9 & 2.6 & 21.5 & 29.7 & 25.9 \\
\hline Conductivity & $\mu \mathrm{S} / \mathrm{cm}$ & 273.8 & 100.5 & 130.0 & 499.0 & 205.0 & 59.6 & 93.3 & 272.0 & 185.1 & 49.2 & 119.7 & 268.5 & 174.2 \\
\hline $\mathrm{Ph}$ & & 5.78 & 0.43 & 5.03 & 6.45 & 6.55 & 0.54 & 5.42 & 7.08 & 7.40 & 1.03 & 6.09 & 8.90 & 8.61 \\
\hline Eh & $\mathrm{mV}$ & 525.3 & 29.9 & 460.7 & 569.0 & 494.6 & 12.3 & 474.0 & 513.7 & 474.0 & 26.7 & 443.0 & 525.3 & 472.5 \\
\hline $\mathrm{O}_{2}$ & $\mathrm{mg} \cdot \mathrm{L}^{-1}$ & 3.45 & 1.12 & 1.54 & 5.60 & 4.52 & 1.11 & 2.01 & 6.31 & 3.79 & 0.54 & 3.19 & 4.59 & 3.19 \\
\hline Cr total & $\mathrm{mg} \cdot \mathrm{L}^{-1}$ & 0.006 & 0.003 & $<0.005$ & 0.013 & 0.013 & 0.006 & 0.005 & 0.025 & 0.051 & 0.045 & 0.013 & 0.12 & 0.120 \\
\hline $\mathrm{Cr}^{6+}$ & $\mathrm{mg} \cdot \mathrm{L}^{-1}$ & 0.002 & 0.003 & $<0.005$ & 0.010 & 0.013 & 0.008 & 0.005 & 0.025 & 0.044 & 0.042 & 0.010 & 0.12 & 0.120 \\
\hline $\mathrm{Na}^{+}$ & $\mathrm{mg} \cdot \mathrm{L}^{-1}$ & 18.29 & 10.20 & 3.60 & 31.00 & 5.35 & 3.130 & 2.60 & 13.30 & 12.42 & 12.61 & 1.98 & 32.00 & 27.00 \\
\hline $\mathrm{K}^{+}$ & $\mathrm{mg} \cdot \mathrm{L}^{-1}$ & 5.94 & 1.76 & 2.30 & 8.90 & 3.90 & 1.140 & 2.60 & 6.27 & 3.170 & 2.55 & 0.30 & 7.77 & 0.44 \\
\hline $\mathrm{Ca}^{2+}$ & $\mathrm{mg} \cdot \mathrm{L}^{-1}$ & 17.73 & 9.82 & 6.52 & 40.50 & 21.04 & 9.620 & 7.73 & 38.05 & 15.64 & 10.55 & 4.30 & 35.20 & 7.18 \\
\hline $\mathrm{Mg}^{2+}$ & $\mathrm{mg} \cdot \mathrm{L}^{-1}$ & 6.36 & 3.09 & 1.30 & 13.65 & 7.34 & 2.600 & 3.25 & 11.00 & 4.46 & 3.16 & 0.35 & 9.20 & 1.88 \\
\hline $\mathrm{Ba}^{2+}$ & $\mathrm{mg} \cdot \mathrm{L}^{-1}$ & 0.30 & 0.16 & 0.08 & 0.77 & 0.22 & 0.100 & 0.08 & 0.42 & 0.15 & 0.10 & 0.03 & 0.35 & 0.03 \\
\hline $\mathrm{Sr}^{2+}$ & $\mathrm{mg} \cdot \mathrm{L}^{-1}$ & 0.16 & 0.08 & 0.06 & 0.33 & 0.16 & 0.090 & 0.03 & 0.31 & 0.25 & 0.21 & 0.07 & 0.58 & 0.15 \\
\hline $\mathrm{HCO}_{3}^{-}$ & $\mathrm{mg} \cdot \mathrm{L}^{-1}$ & 23.31 & 14.90 & 6.10 & 51.85 & 85.30 & 58.90 & 15.25 & 183.0 & 90.52 & 40.99 & 40.41 & 154.0 & 105.2 \\
\hline $\mathrm{CO}_{3}^{-}$ & $\mathrm{mg} \cdot \mathrm{L}^{-1}$ & - & - & - & - & - & - & - & - & - & - & 9.00 & 15.00 & 9.00 \\
\hline $\mathrm{Cl}^{-}$ & $\mathrm{mg} \cdot \mathrm{L}^{-1}$ & 22.19 & 13.06 & 5.73 & 45.58 & 6.65 & 6.470 & 0.36 & 22.12 & 2.66 & 1.39 & 0.89 & 4.09 & 0.90 \\
\hline $\mathrm{SO}_{4}^{2-}$ & $\mathrm{mg} \cdot \mathrm{L}^{-1}$ & 0.69 & 0.67 & 0.180 & 2.46 & 0.28 & 0.512 & 0.01 & 1.72 & 0.16 & 0.075 & 0.08 & 0.26 & 0.14 \\
\hline $\mathrm{NO}_{3}^{-}$ & $\mathrm{mg} \cdot \mathrm{L}^{-1}$ & 78.79 & 31.80 & 37.29 & 161.8 & 34.73 & 24.54 & 1.46 & 69.18 & 15.14 & 12.74 & 0.08 & 35.15 & 0.37 \\
\hline $\mathrm{PO}_{4}^{3-}$ & $\mathrm{mg} \cdot \mathrm{L}^{-1}$ & 0.08 & 0.04 & 0.04 & 0.18 & 0.12 & 0.100 & 0.01 & 0.30 & 0.11 & 0.11 & 0.03 & 0.36 & 0.03 \\
\hline $\mathrm{F}^{-}$ & $\mathrm{mg} \cdot \mathrm{L}^{-1}$ & 0.08 & 0.04 & 0.03 & 0.16 & 0.12 & 0.060 & 0.03 & 0.20 & 0.14 & 0.035 & 0.08 & 0.19 & 0.15 \\
\hline Fe total & $\mathrm{mg} \cdot \mathrm{L}^{-1}$ & 0.03 & 0.03 & $<0.01$ & 0.09 & 0.02 & 0.030 & $<0.01$ & 0.07 & 0.025 & 0.017 & 0.01 & 0.05 & $<0.01$ \\
\hline $\mathrm{Mn}^{2+}$ & $\mathrm{mg} \cdot \mathrm{L}^{-1}$ & 0.07 & 0.09 & 0.01 & 0.31 & 0.01 & 0.010 & $<0.01$ & 0.04 & 0.01 & 0.02 & $<0.01$ & 0.05 & $<0.01$ \\
\hline $\begin{array}{l}\text { Sat.Ind.** } \\
\text { Calcite }\end{array}$ & & -3.09 & & & & -1.65 & & & & & & & & +0.09 \\
\hline $\begin{array}{l}\text { Sat.Ind. } \\
\text { Dolomite }\end{array}$ & & -6.09 & & & & -3.23 & & & & & & & & +0.12 \\
\hline
\end{tabular}

(1) $\mathrm{N}$ wells = number of wells; Std.: standard deviation; Min.: minimum; Max.: maximum; Sat.Ind. = saturation index. (2) Concentrations in italic and lower case highlight elevated values of standard deviation, indicating that the mean value is not a representative figure.

Reaction 2 decreases $\mathrm{Ca}^{2+}$ concentration and seems to control the dissolution of carbonate minerals, driving reaction 1 to the right, increasing the $\mathrm{pH}$ and $\mathrm{HCO}_{3^{-}}$concentration. Table V summarizes the hydrogeochemical processes identified in the aquifer.

\section{Behavior of chromium concentrations}

Chromium concentrations also showed distinct behavior at different depths in the aquifer (Fig. 4), with an increase from the shallow to deep zones (Table IV). Ten of the 14 shallow wells showed non-detected concentrations of chromium, whereas the remaining wells showed low concentrations (maximum of $0.013 \mathrm{mg} \cdot \mathrm{L}^{-1}$ ). Chromium was detected in all 10 intermediate wells, although at low concentrations, ranging from the detection limit to $0.025 \mathrm{mg} . \mathrm{L}^{-1}$. All deep wells showed the detection of chromium at concentrations that were generally higher than those found at intermediate depths. Three of the 7 samples showed concentrations exceeding the potability limit $\left(0.05 \mathrm{mg} . \mathrm{L}^{-1}\right)$.

$\mathrm{Cr}_{\text {total }}$ and $\mathrm{Cr}^{6+}$ concentrations are usually similar (Table IV), except in the case of the shallow wells, indicating that dissolved chromium in groundwater is essentially present in its hexavalent form at the intermediate and deep aquifer levels. This is in accordance with the oxidizing environment and elevated $\mathrm{pH}$ conditions that were observed, except in the case of the shallow zone of the aquifer, where $\mathrm{Cr}^{3+}$ is predominant (based on PhreeqC modeling), due to the relatively low $\mathrm{pH}$. 
TABLE V

Summary of hydrogeochemical processes identified in the 3 different hydraulic zones studied.

\begin{tabular}{|c|c|c|c|}
\hline & Shallow aquifer & Intermediate aquifer & Deep aquifer \\
\hline Environment & $\begin{array}{l}\text { Acidic waters under } \\
\text { oxidizing conditions }\end{array}$ & $\begin{array}{l}\text { Acidic to neutral waters } \\
\text { under oxidizing conditions }\end{array}$ & $\begin{array}{l}\text { Alkaline waters under } \\
\text { oxidizing conditions }\end{array}$ \\
\hline Water type & $\mathrm{Na}-\mathrm{Ca}-\mathrm{Cl}-\mathrm{NO}_{3}$ & $\mathrm{Ca}-\mathrm{HCO}_{3}$ & $\mathrm{Na}-\mathrm{Ca}-\mathrm{HCO}_{3}$ \\
\hline Cations & $\begin{array}{l}\mathrm{Na}^{+} \text {and } \mathrm{Ca}^{2+}>\mathrm{Mg}^{2+} \\
\text { and } \mathrm{K}^{+}\end{array}$ & $\begin{array}{l}\uparrow \mathrm{Ca}^{2+} \text { and } \mathrm{Mg}^{2+} \\
\downarrow \mathrm{Na}^{+} \text {and } \mathrm{K}^{+}\end{array}$ & $\begin{array}{l}\uparrow \mathrm{Na}^{+} \\
\downarrow \mathrm{K}^{+}, \mathrm{Ca}^{2+} \mathrm{e} \mathrm{Mg}^{2+}\end{array}$ \\
\hline Anions & $\mathrm{NO}_{3}^{-}>\mathrm{HCO}_{3}^{-}$and $\mathrm{Cl}^{-}$ & $\begin{array}{l}\uparrow \mathrm{HCO}_{3}^{-} \\
\downarrow \mathrm{NO}_{3}^{-} \text {and } \mathrm{Cl}^{-}\end{array}$ & $\begin{array}{l}\uparrow \mathrm{HCO}_{3}^{-} \\
\downarrow \downarrow \mathrm{NO}_{3}^{-} \text {and } \mathrm{Cl}^{-}\end{array}$ \\
\hline $\begin{array}{l}\text { Molar ratios } \\
\left(\mathrm{meq} . \mathrm{L}^{-1 /}\right. \\
\left.\text { meq. } \mathrm{L}^{-1}\right) \\
\end{array}$ & $\begin{array}{l}\mathrm{Na}^{+} / \mathrm{Cl}^{-}=1.2 \\
\mathrm{Ca}^{2+} / \mathrm{HCO}_{3}^{-}=2.3\end{array}$ & $\begin{array}{l}\mathrm{Na}^{+} / \mathrm{Cl}^{-}=1.2 \\
\mathrm{Ca}^{2+} / \mathrm{HCO}_{3}^{-}=0.7\end{array}$ & $\begin{array}{l}\mathrm{Na}^{+} / \mathrm{Cl}^{-}=46.3 \\
\mathrm{Ca}^{2+} / \mathrm{HCO}_{3}^{-}=0.4\end{array}$ \\
\hline $\begin{array}{l}\text { Geochemical } \\
\text { processes - } \\
\text { Major } \\
\text { constituents }\end{array}$ & $\begin{array}{l}\text { Low } \mathrm{pH} \text { and most of the } \mathrm{Na}^{+} \text {, } \\
\mathrm{NO}_{3}^{-} \text {and } \mathrm{Cl}^{-} \text {concentrations are } \\
\text { attributed to contamination by } \\
\text { septic systems and/or fertilizer } \\
\text { use. Conditions for dissolution } \\
\text { of carbonate minerals. }\end{array}$ & $\begin{array}{l}\text { Hydraulic dispersion of the } \\
\text { contaminants. Dissolution of } \\
\text { carbonate minerals, increasing } \\
\mathrm{pH} \text { and } \mathrm{Ca}^{2+} \text { and } \mathrm{HCO}_{3}^{-} \\
\text {concentrations. }\end{array}$ & $\begin{array}{l}\text { Cation exchange of } \mathrm{Na}^{+} \text {by } \\
\mathrm{Ca}^{2+} \text { and } \mathrm{Mg}^{2+} . \text { Dissolution of } \\
\text { carbonate minerals up to their } \\
\text { solubility limits. Dissolution of } \\
\text { carbonate minerals affected } \\
\text { by cation exchange reaction, } \\
\text { increasing pH and } \mathrm{HCO}_{3}^{-} \\
\text {concentrations. }\end{array}$ \\
\hline Chromium & $\begin{array}{l}\text { Low to very low } \\
\text { concentrations (usually } \\
\text { non-detect); } \\
\mathrm{Cr}^{3+} \text { predominant. } \\
\mathrm{Mn}^{2+} \text { usually detected. }\end{array}$ & $\begin{array}{l}\text { Low concentrations } \\
\left.\text { (max. } 0.025 \mathrm{mg} . \mathrm{L}^{-1}\right) \\
\mathrm{Cr}^{6+} \text { predominant. }\end{array}$ & $\begin{array}{l}\text { Moderate to high concentrations } \\
\text { (max. } 0.120 \text { mg. } \mathrm{L}^{-1} \text { ); } \\
\mathrm{Cr}^{6+} \text { predominant; } \\
(+) \text { correlation with } \mathrm{pH}, \mathrm{Na}^{+} \\
\text {and total alkalinity; } \\
(-) \text { correlation with } \mathrm{NO}_{3}^{-} \text {. } \\
\mathrm{Mn}^{2+} \text { usually not detected. }\end{array}$ \\
\hline $\begin{array}{l}\text { Possible } \\
\text { geochemical } \\
\text { processes - } \\
\text { Chromium }\end{array}$ & $\begin{array}{l}\text { Pyroxene weathering; } \\
\mathrm{Cr}^{3+} \text { cations predominate in } \\
\text { the form of hydroxides and/or } \\
\text { adsorbed onto clay/ } \\
\text { hydroxides minerals; } \\
\text { Possible reduction of } \mathrm{Cr}^{6+} \\
\text { into } \mathrm{Cr}^{3+} \text { by organic matter, } \\
\mathrm{NH}_{4}^{+}, \mathrm{NO}_{2}^{-} \text {and/or } \mathrm{Fe}^{2+} \text {. }\end{array}$ & $\begin{array}{l}\text { Possible pyroxene weathering; } \\
\text { Oxidation of } \mathrm{Cr}^{3+} \text { to } \mathrm{Cr}^{6+} \\
\text { by } \mathrm{MnO}_{2} \text {; } \\
\text { Adsorption of } \mathrm{Cr}^{6+} \text { anions } \\
\text { by } \mathrm{Al} \text { and } \mathrm{Fe} \text { hydroxides. }\end{array}$ & $\begin{array}{l}\text { Oxidation of } \mathrm{Cr}^{3+} \text { to } \mathrm{Cr}^{6+} \\
\text { by } \mathrm{MnO}_{2} \text {; } \\
\text { Increased } \mathrm{pH} \text { and presence } \\
\text { of competing anions cause } \\
\text { desorption and mobilization } \\
\text { of } \mathrm{Cr}^{6+} \text { anions. }\end{array}$ \\
\hline
\end{tabular}

$\uparrow$ or $\downarrow$ : elevation or decrease of concentrations in respect to the previous shallower aquifer level.

Correlation coefficients between chromium and the other chemical components were obtained. Except for significant correlations of $\mathrm{Cr}$ with $\mathrm{pH}(\mathrm{R}=0.80)$ and $\mathrm{NO}_{3^{-}}(\mathrm{R}=-0.61)$ (Fig. 5), no statistically linear or inverse relationships were found in comparing chromium with other chemical species or physical parameters. As suggested in Figure 4, $\mathrm{pH}, \mathrm{Cr}^{6+}$ and $\mathrm{NO}_{3}$ - box plots showed different patterns between shallow, intermediate and deep wells.

Solely considering data regarding intermediate and deep wells, in order to reduce the main influence of cesspit contamination observed in the shallow aquifer, a correlation between $\mathrm{Cr}^{6+}$ and $\mathrm{pH}, \mathrm{NO}_{3^{-}}, \mathrm{Na}^{+}$and total alkalinity has been observed (Fig. 5). The highest concentrations of chromium were observed in three deep wells (PP04 included), where the highest values of $\mathrm{pH}$, $\mathrm{Na}^{+}$and total alkalinity were found, as well as the lowest concentrations of $\mathrm{NO}_{3}{ }^{-}$.

$\mathrm{Cr}^{6+}$ and $\mathrm{Mn}^{2+}$ concentrations showed contrasting tendencies, although no statistical correlation was found between them. $\mathrm{Mn}^{2+}$ was detected in all 14 shallow wells, while it was detected in lower concentrations in only 5 of 17 wells representing the intermediate and deep aquifers. The opposite behavior was observed in the case of $\mathrm{Cr}^{6+}$. 

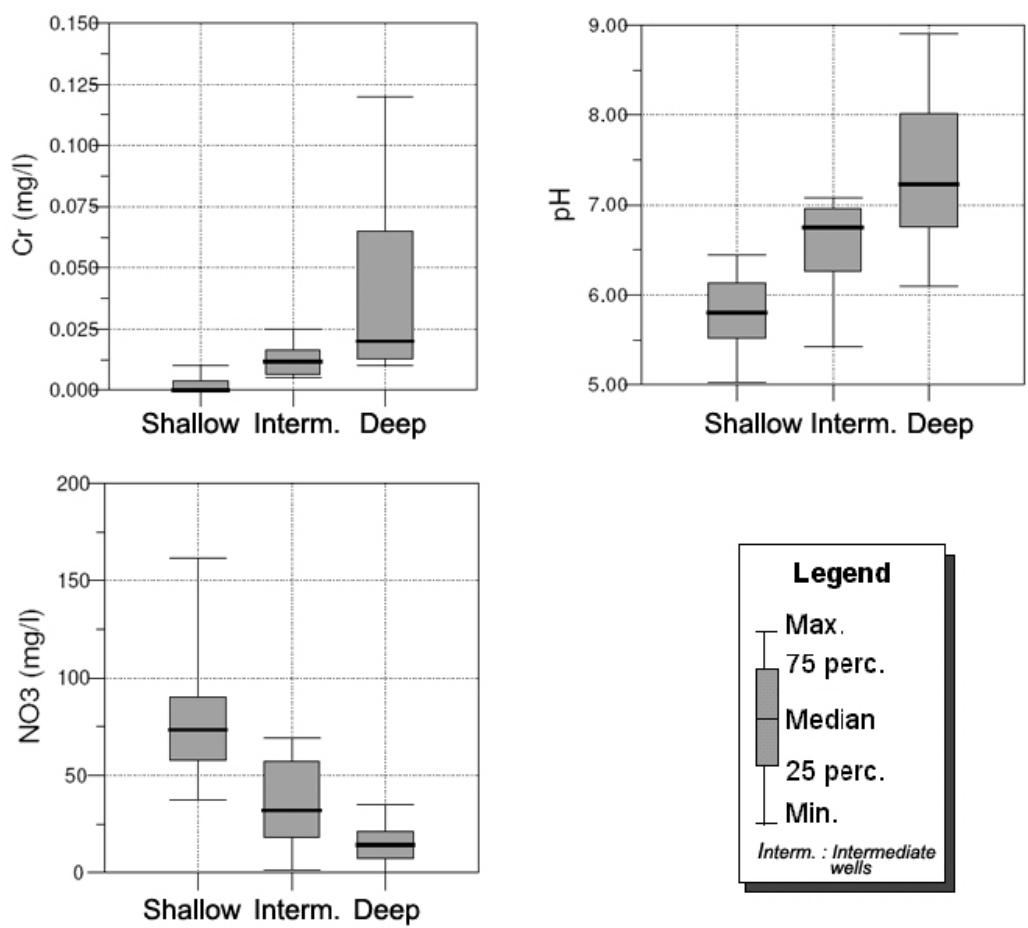

Fig. 4 - Box plots showing a comparison of chromium, $\mathrm{pH}$ and nitrate distribution for groundwater samples from shallow, intermediate and deep wells.

Sampling throughout different pumping intervals was performed over a 24-hours period with a constant flow rate in the public 6" wells (deep wells) PP02 and PP04. Samples were collected at $15 \mathrm{~min}$, and then at 1 , $6,12,18$ and $24 \mathrm{~h}$ after the start of pumping. The results indicate that $\mathrm{pH}$ values and $\mathrm{Cr}^{6+}$ and $\mathrm{Na}^{+}$concentrations increase in both deep wells over the pumping period, whereas $\mathrm{NO}_{3}$ - concentrations decrease (Fig. 6).

Given that the characteristics of the aquifer are considered to be of the unconfined to semiconfined type, continuous pumping allows for the capture of deeper flows in the aquifer, represented by older waters that have been subject to a longer period of water-rock interaction. The observed relationships between $\mathrm{Cr}^{6+}, \mathrm{pH}, \mathrm{Na}^{+}$and $\mathrm{NO}_{3}{ }^{-}$ during this experiment are in accordance with the correlations observed in Figure 5.

\section{Possible geochemical reactions involving chromium}

Aqueous concentrations of chromium are dependent upon the chemistry of trivalent and hexavalent chromium species and are controlled by processes such as the precipitation/dissolution of chromium minerals, redox transformation of $\mathrm{Cr}^{3+} / \mathrm{Cr}^{6+}$ and adsorption/desorption of $\mathrm{Cr}^{3+} / \mathrm{Cr}^{6+}$ onto mineral surfaces.

According to Richard and Bourg (1991), $\mathrm{Cr}^{6+}$ minerals are very scarce in nature and amorphous $\left[\mathrm{Fe}^{3+}\right.$, $\left.\mathrm{Cr}^{3+}\right]$ hydroxide is probably the main phase controlling chromium solubility in natural environments. However, the chemical and mineralogical analyses conducted in this investigation indicated high concentrations of chromium in sandstones (average of $221 \mathrm{ppm}$ ), and especially in pyroxene (augite) crystals (6000 ppm), which is one of the main heavy minerals found in the sandstone. Pyroxene is one of the most reactive minerals in weathering processes, according to the Goldich stability series (Kehew 2001), thus, this mineral may be considered as the main source of chromium found in water. However, chromium occurs as $\mathrm{Cr}^{3+}$ in pyroxenes and a redox reaction must take place to make $\mathrm{Cr}^{6+}$ available and found in groundwater.

The redox process for transformation of $\mathrm{Cr}^{3+}$ into $\mathrm{Cr}^{6+}$ can take place in the presence of another redox couple, such as $\mathrm{H}_{2} \mathrm{O} / \mathrm{O}_{2}$ (aq.) and $\mathrm{Mn}^{2+} / \mathrm{Mn}^{4+}$ in natural aquatic environments (Richard and Bourg 1991). Dissolved oxygen was found to oxidize small amounts 

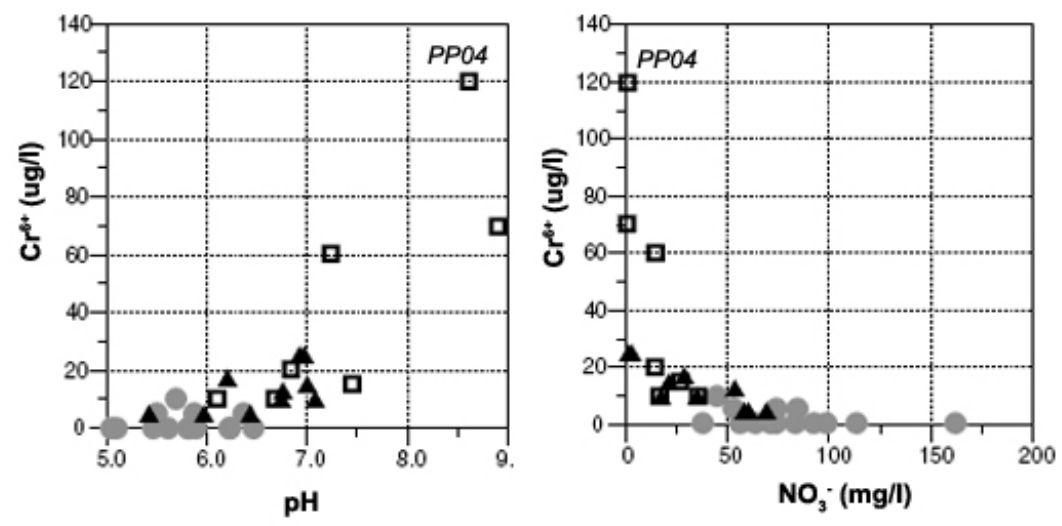

Shallow $\Delta$ Intermediate $\square$ Deep
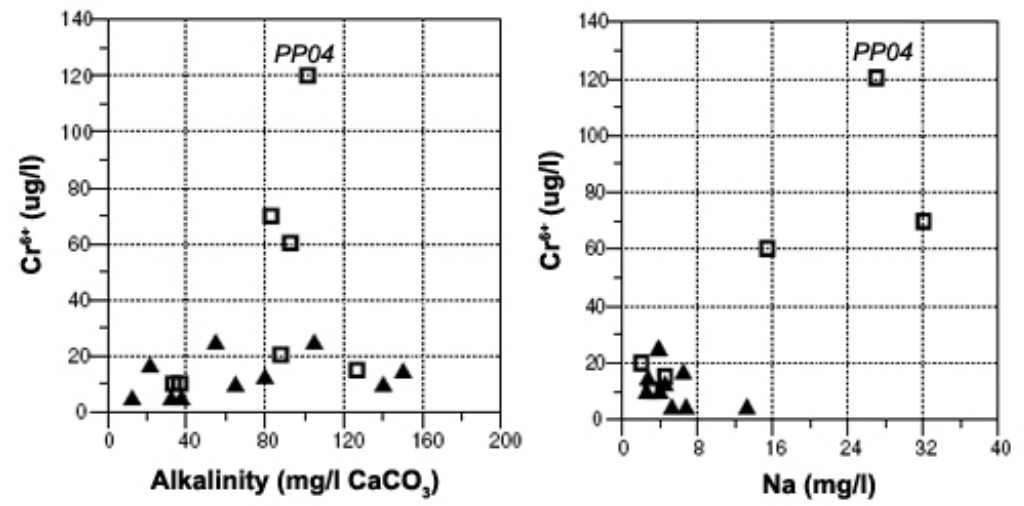

\section{$\Delta$ Intermediate $\square$ Deep}

Fig. 5 - Relationship between hexavalent chromium concentrations and $\mathrm{pH}$, nitrate, alkalinity and sodium concentrations.

of $\mathrm{Cr}^{3+}$ into $\mathrm{Cr}^{6+}$ at $\mathrm{pH}$ values greater than 9 (Fendorf and Zasoski 1992), however, according to Richard and Bourg (1991), the rate of oxidation is very slow and enables $\mathrm{Cr}^{3+}$ to be involved in faster concurrent reactions, like sorption or precipitation. Considering that the residence time of water in aquifers may reach thousands of years and $\mathrm{pH}$ values are quite elevated in the deep aquifer, the possibility cannot be neglected that this reaction may occur.

However, manganese oxides, generally present as grain coatings, crack deposits or finely disseminated grains, are known to be the main agent responsible for the oxidation of $\mathrm{Cr}^{3+}$ to $\mathrm{Cr}^{6+}$ in aquifers (Apte et al. 2006, Sedlak and Chan 1997, Richard and Bourg 1991, Eary and Rai 1987, Fendorf and Zazoski 1992, Fendorf 1995, Bartlett and James 1979).

$$
\begin{aligned}
& \mathrm{Cr}^{3+}+1.5 \mathrm{Mn}^{\mathrm{iv}} \mathrm{O}_{2}(\mathrm{~s})+\mathrm{H}_{2} \mathrm{O} \\
& =\mathrm{HCrO}_{4^{-}}+1.5 \mathrm{Mn}^{2+}+\mathrm{H}^{+}
\end{aligned}
$$

This reaction is more effective under acidic conditions. According to this reaction, one might expect that $\mathrm{Cr}^{6+}$ would exhibit a correlation with dissolved manganese $\left(\mathrm{Mn}^{2+}\right)$ in water, although this is not observed in the current results, given that $\mathrm{Mn}^{2+}$ is frequently not detected in 



Fig. 6 - Variation of $\mathrm{pH}$ values and chromium, nitrate and sodium concentrations throughout pumping period.

the deep aquifer, where $\mathrm{Cr}^{6+}$ concentrations are higher. However, any $\mathrm{Mn}^{2+}$ formed during $\mathrm{Cr}^{3+}$ oxidation will be converted back to $\mathrm{MnO}_{2}$ in the presence of dissolved oxygen (Apte et al. 2006), which is observed in all depths in the aquifer in Urânia. In fact, chromium and manganese form a pair of chemical elements of opposite tendencies, since, under oxidizing conditions, $\mathrm{Cr}^{6+}$ is soluble as $\mathrm{CrO}_{4}^{2-}$ and $\mathrm{Mn}^{4+}$ is present as $\mathrm{MnO}_{2}$; under reducing conditions, $\mathrm{Cr}^{3+}$ is removed from solution as $\mathrm{Cr}(\mathrm{OH})_{3}$ and $\mathrm{Mn}^{2+}$ is soluble (Richard and Bourg 1991). The same relationship (inverse correlation between $\mathrm{Cr}^{6+}$ and $\mathrm{Mn}^{2+}$ ) has also been observed by Gonzalez et al. (2005) in the Aroma Red Sands Aquifer in California.
In the shallow aquifer, more acidified waters contribute to more intensive weathering of pyroxenes, and $\mathrm{Cr}^{3+}$ rapidly precipitates as hydroxides or is adsorbed by $\mathrm{Fe}$ and Mn hydroxides (Richard and Bourg 1991). Part of the possible $\mathrm{Cr}^{6+}$ produced in the shallow aquifer might be reduced back to $\mathrm{Cr}^{3+}$ by organic matter (aminoacids and humic or fulvic acids) or by $\mathrm{Fe}^{2+}$ oxidation, which are fast reactions. Nitrification processes, which convert ammonium to nitrate, acidify waters and may also contribute to the immobilization of $\mathrm{Cr}^{3+}$ (Charlet and Manceau 1992, Rai et al. 1989).

Adsorption is a very important process that controls the mobility of chromium. $\mathrm{Cr}^{3+}$ is rapidly and strongly 
immobilized by adsorption to clay minerals (low $\mathrm{pH}_{\mathrm{zpc}}$ minerals), a process that increases with $\mathrm{pH}$ (Richard and Bourg 1991).

Due to its anionic nature, $\mathrm{Cr}^{6+}$ is preferentially retained on positively charged surfaces, for example, Al and $\mathrm{Fe}$ hydroxides (high $\mathrm{pH}_{\mathrm{zpc}}$ minerals), principally in more acidic conditions. In addition, most of the $\mathrm{Cr}^{6+}$ produced by $\mathrm{Cr}^{3+}$ oxidation reactions may be adsorbed by these minerals in the intermediate and deep portions of the aquifer.

However, adsorption of $\mathrm{Cr}^{6+}$ to minerals strongly decreases in the alkaline $\mathrm{pH}$ range and in the presence of other competing anions, increasing its mobility (Rai et al. 1989, Zachara et al. 1987). This may be the most probable phenomenon occurring in the deep aquifer, since the anomalous increase in $\mathrm{pH}$, probably driven by cation exchange reactions involving $\mathrm{Na}^{+}, \mathrm{Ca}^{2+}$ and $\mathrm{Mg}^{2+}$ and by the dissolution of carbonate minerals up to their solubility limits (reactions 1 and 2), is likely causing the desorption of $\mathrm{Cr}^{6+}$ anions to the aquifer. Table $\mathrm{V}$ summarizes possible geochemical processes involving chromium in the different parts of the aquifer.

\section{CONCLUSIONS}

Chromium is found in groundwater of the Adamantina Aquifer, at concentrations often exceeding the established potability limit $\left(0.05 \mathrm{mg} . \mathrm{L}^{-1}\right)$, in an extensive area covering at least 54 municipalities located in the northwestern region of the State of São Paulo. An investigation conducted in the municipality of Urânia, where the highest concentrations were found, indicated that the origin of this contamination is natural, since elevated concentrations of chromium were detected in sandstones (average of $221 \mathrm{ppm}$ ) and especially in the mineral augite (6000 ppm), which is the main heavy mineral found in the sandstone. Besides this, no possible diffuse or point sources of contamination were observed in the study area. The results obtained for Urânia are good indication that the chromium found in groundwater regionally may have the same origin.

The distribution of chromium concentrations in the different hydrochemical and hydraulic zones of the aquifer in Urânia clearly shows that the highest concentrations originate in the deeper aquifer levels, where groundwater is older, the rock-water interaction is longer and hydrochemical conditions allow chromium release into aqueous solution. In most of the groundwater samples collected from the shallow wells, chromium has not been detected or observed concentrations are very low. The distribution pattern of these concentrations also reinforces the hypothesis that the origin of chromium is natural. Dissolved chromium is essentially present in its hexavalent form, especially at the intermediate and deep levels of the aquifer.

The origin of $\mathrm{Cr}^{6+}$ seems to be associated with the weathering of $\mathrm{Cr}$-minerals, such as the $\mathrm{Cr}$-augite identified, followed by the redox transformation of $\mathrm{Cr}^{3+}$ into $\mathrm{Cr}^{6+}$ by another redox couple, for example, $\mathrm{H}_{2} \mathrm{O} / \mathrm{O}_{2}$ (aq.) or $\mathrm{Mn}^{2+} / \mathrm{Mn} 4+$. According to many authors, manganese oxides are most likely responsible for $\mathrm{Cr}^{3+}$ oxidation. The processes of adsorption/desorption of $\mathrm{Cr}^{6+}$ probably represent important reactions, since the highest $\mathrm{Cr}^{6+}$ concentrations are found in the deep aquifer, where groundwater $\mathrm{pH}$ is more alkaline, which is a condition necessary for the desorption of $\mathrm{Cr}^{6+}$. This phenomenon may be occurring in the deep aquifer, where cation exchange reactions are driving the dissolution of carbonate minerals, causing an anomalous increase in $\mathrm{pH}$. Complementary field and laboratory studies are now being conducted in order to confirm the occurrence of such geochemical processes responsible for the presence of chromium in groundwater.

\section{ACKNOWLEDGMENTS}

The authors are indebted to Fundação de Amparo à Pesquisa do Estado de São Paulo (FAPESP) for financial support of the project (processes 97/13879-6, 98/153400 and 05/60502-3). Bourotte has received a post-doctoral grant from Conselho Nacional de Desenvolvimento Científico e Tecnológico (CNPq) (No. 154492/2006-0).

\section{RESUMO}

Concentrações anômalas de cromo hexavalente foram detectadas em águas subterrâneas do Aqüífero Adamantina em pelo menos 54 municipalidades localizadas na região noroeste do Estado de São Paulo, sudeste do Brasil, algumas vezes ultrapassando o limite máximo permitido para consumo humano $\left(0,05 \mathrm{mg} . \mathrm{L}^{-1}\right)$. Um estudo foi realizado no município de Urânia, onde as mais elevadas concentrações de cromo da região foram detectadas. A origem da contaminação foi definida 
como natural, pois foram detectadas concentrações de cromo nos arenitos do aqüífero (média 221 ppm) e em piroxênios (6000 ppm), um dos principais minerais pesados encontrados nos sedimentos. Além disso, não foram observadas outras possíveis fontes de contaminação difusas ou pontuais na área de estudo. Uma estratificação da qualidade da água no aqüífero foi observada e as mais elevadas concentrações de $\mathrm{Cr}^{6+}$ foram detectadas na base do aqüífero $\left(0,12 \mathrm{mg} . \mathrm{L}^{-1}\right)$, onde as águas subterrâneas apresentam valores elevados de potencial redox $(\mathrm{Eh}=472,5 \mathrm{mV})$ e de $\mathrm{pH}(8,61)$. A origem do $\mathrm{Cr}^{6+}$ na água deve estar associada com o intemperismo do piroxênio (augita), seguida da oxidação do $\mathrm{Cr}^{3+}$ pelos óxidos de manganês. As maiores concentrações de $\mathrm{Cr}^{6+}$ estão provavelmente ligadas com reações de desorção, devido ao $\mathrm{pH}$ anomalamente alcalino da água subterrânea na base do aqüífero.

Palavras-chave: cromo, água subterrânea, aqüífero, contaminação natural.

\section{REFERENCES}

Almodovar MLN. 2000. A origem natural da poluição por cromo no Aqüífero Adamantina, município de Urânia, São Paulo, (In Portuguese - The origin of natural pollution by chromium in the Adamantina Aquifer, Urânia municipality, São Paulo), Ph.D. thesis, Institute of Geosciences, University of São Paulo, 199 p.

Almodovar MLN And Pacheco A. 1995. Anomalia de Cromo nas Águas Subterrâneas de Urânia no Noroeste do Estado de São Paulo. Boletim IG-USP: Série Científica 26: $1-12$.

Appelo CAJ And Postma D.1993. Geochemistry, Groundwater and Pollution. Taylor and Francis Books, London, $649 \mathrm{p}$.

Apte AD, TARe V and Bose P. 2006. Extent of oxidation of $\mathrm{Cr}$ (III) to $\mathrm{Cr}$ (VI) under various conditions pertaining to natural environment. J Hazard Mater B128: 164-174.

ATSDR. 2000. Toxicological profile for Chromium. Agency for Toxic Substances and Disease Registry, U.S. Department of Health and Human Services, $461 \mathrm{p}$.

BALL JW AND IZBICKI JA. 2004. Occurrence of hexavalent chromium in ground water in the wester Mojave Desert, California. Appl Geochem 19: 1123-1135.

BARTLETT RJ AND JAMES B. 1979. Behavior of chromium in soils: III. Oxidation. J Environ Qual 8: 31-35.

Brandt Neto M, Petri S And Coimbra AM. 1985. Argilominerais do Grupo Bauru: considerações genéticas. In: Simpósio Regional de Geologia, 5, São Paulo. Atas. São Paulo, SBG - Núcleo São Paulo 1: 61-74.
Charlet L And Manceau AA. 1992. X-Ray absorption spectroscopic study of the sorption of $\mathrm{Cr}^{3+}$ at the oxidewater interface II. Adsorption, coprecipitation and surface precipitation on hydrous ferric oxide. J Colloid Interface Sci 148: 443-458.

DAEE - Departamento de Águas e Energia ElétriCA. 1976. Estudo de Águas Subterrâneas. Região Administrativa 7, 8 e 9, Bauru, São José do Rio Preto e Araçatuba. 4v. São Paulo, Brasil.

EARY LE AND RAI D. 1987. Kinetics of Chromium(III) oxidation to Chromium(VI) by reaction with manganese dioxide. Environ Sci Technol 21: 1187-1193.

FENDORF SE. 1995. Surface reactions of chromium in soils and waters. Geoderma 67: 55-71.

Fendorf SE And Zasoski RJ. 1992. Chromium(III) oxidation by $\delta-\mathrm{MnO}_{2}$ 1. Characterization. Environ Sci Technol 26: 79-85.

FERNANDES LA AND COIMBRA AM. 2000. Revisão estratigráfica da parte oriental da Bacia Bauru (Neocretáceo). Rev bras Geocienc 30: 723-734.

Gonzalez AR, Ndundu K And Flegal AR. 2005. Natural occurrence of hexavalent chromium in the Aromas Red Sands Aquifer, California. Environ Sci Technol 39: 5505-5511.

Hirata R, Bastos C. And Rocha G. 1997. Mapeamento da vulnerabilidade a poluição dos aqüíferos do Estado de São Paulo. Secretaria do Meio Ambiente do Estado de São Paulo. São Paulo, 2v.

KeHEW AE. 2001. Applied chemical hydrogeology. Prentice-Hall. 368 p.

Marcolan L and Bertolo R. 2007. Anomalias Geoquímicas de Cromo em Arenitos da Formação Adamantina em Urânia - SP. XI Congresso Brasileiro de Geoquímica. Atas, CD, 4 p.

PARKhURST DL AND APPELO AAJ. 1999. User's guide do PHREEQC (version 2) - A computer program for speciation, batch-reaction, one dimensional transport and inverse geochemical modeling. US Geol. Survey, Waterresource Invest.

RAI D, EARY LE AND ZACHARA JM. 1989. Environmental chemistry of chromium. Sci Total Environ 86: 15-23.

RICHARD FC AND BourG ACM. 1991. Aqueous geochemistry of chromium: a review. Water Res 25: 807-816.

ROBERTSON FN. 1995. Geochemistry of ground water in alluvial basins of Arizona and adjacent parts of Nevada, New Mexico and California. U.S. Geological Survey professional paper 1406-C, $90 \mathrm{p}$. 
Robles-CAmacho J AND ARMienta MA. 2000. Natural chromium contamination of groundwater at León Valley, México. J Geochem Explor 68: 167-181.

SEDLAK DL AND CHAN PG. 1997. Reduction of hexavalent chromium by ferrous iron. Geochim Cosmochim Acta 61: 2185-2192.

SoARES PC, LANDim PMB, FÚlFARo VJ AND Sobreiro Neto AF. 1980. Ensaios de caracterização estratigráfica do Cretáceo no Estado de São Paulo: Grupo Bauru. Rev bras Geocienc 10: 177-185.
ZACHARA JM, GIRVIN DC, SCHMIDT RL AND RESCH CT. 1987. Chromate adsorption on amorphous iron oxyhydroxide in the presence of major groundwater ions. Environ Sci Technol 21: 589-594. 